\title{
Mengenal pasti Faktor Personaliti 'Big Five' Terhadap Prestasi Pembelajaran: Satu Kajian Sistematik
}

\section{(Identifying the Big Five Personality Factors Towards Learning Performance: A Systematic Review)}

\author{
Zawiyah binti Zali*, Shahlan bin Surat ${ }^{2}$ \\ 1Fakulti Pendidikan, Universiti Kebangsaan Malaysia (UKM), 43600, Bangi, Selangor, Malaysia. \\ Email: zawiyah80@gmail.com \\ ${ }^{2}$ Fakulti Pendidikan, Universiti Kebangsaan Malaysia (UKM), 43600, Bangi, Selangor, Malaysia. \\ Email: drshahlan@ukm.edu.my
}

\section{CORRESPONDING \\ AUTHOR (*): \\ Zawiyah binti Zali \\ (zawiyah80@gmail.com)}

\section{KATA KUNCI:}

Personaliti big five

Pencapaian akademik

Personaliti

\section{KEYWORDS:}

Personality big five

Academic achievement

Personality

\section{CITATION:}

Zawiyah Zali \& Shahlan Surat. (2022).

Mengenal pasti Faktor Personaliti 'Big Five'

Terhadap Prestasi Pembelajaran: Satu

Kajian Sistematik. Malaysian Journal of

Social Sciences and Humanities (MJSSH),

7(2), e001271.

https://doi.org/10.47405/mjssh.v7i2.1271

\section{ABSTRAK}

Tret personaliti 'big five' diterima pakai dalam semua kajian personaliti yang terlibat dalam kajian psikologi sosial dan telah menghasilkan banyak artikel yang meliputi aspek psikologi, sains pendidikan, teknologi dan pelbagai aspek yang lain. Tujuan kajian ini dijalankan adalah untuk melakukan tinjauan secara sistematik terhadap perhubungan antara tret personaliti 'big five' dan pencapaian akademik pelajar. Selain daripada itu, kajian ini bertujuan untuk mengenal pasti tret personaliti yang paling dominan mempengaruhi pencapaian akademik pelajar. Melalui enjin carian pangkalan data Science Direct, dua puluh artikel kajian yang menepati kriteria pemilihan telah dipilih. Hasil daripada analisis menunjukkan bahawa tret kehematan merupakan tret personaliti yang paling mempengaruhi pencapaian akademik pelajar. Manakala tret neurotisme merupakan tret personaliti yang paling tidak memberi kesan terhadap pencapaian akademik pelajar.

\section{ABSTRACT}

The big five personality traits are adopted in all personality studies involved in social psychology studies and have produced many articles covering aspects of psychology, educational science, technology and various other aspects. The purpose of this study was to conduct a systematic study of the relationship between the top five personality traits with students 'academic achievement. In addition, this study aimed to identify the most dominant personality traits influencing students 'academic achievement. Through the Science Direct database search engine, twenty research articles that met the selection criteria were selected. The results of the analysis show that conscientiousness is the personality trait that most influences students' academic achievement. While the nature of neuroticism is a personality trait that does not affect students' academic achievement. 
Sumbangan/Keaslian: Kajian ini dapat menyumbang kepada literatur sedia ada tentang kesan personaliti 'big five' terhadap pencapaian akademik pelajar. Selain daripada itu, kajian ini dapat dijadikan panduan dan rujukan kepada guru-guru dan pensyarah untuk memberi lebih perhatian kepada tret kehematan dan keterbukaan sebagai peramal kepada pencapaian akademik pelajar.

\section{Pengenalan}

Secara umumnya, diri manusia mengandungi dua aspek iaitu, kemampuan dan personaliti (Norhaiza, 2015). Aspek kemampuan meliputi pencapaian dalam pembelajaran, kecerdasan dan bakat seseorang. Manakala personaliti meliputi watak, sifat, penyesuaian diri, minat, emosi, sikap dan motivasi. Dari segi istilah, personaliti berasal daripada bahasa Inggeris yang diterjemahkan daripada perkataan Latin, iaitu 'persona'. Perkataan persona membawa erti topeng muka iaitu topeng yang digunakan oleh pelakon-pelakon teater Yunani di atas pentas. Perkataan persona berubah menjadi gambaran sosial yang diterima oleh individu dalam kelompok masyarakat (Abd Rahman, 2010). Seterusnya, Allen dan Walter (2018) mendefinisikan personaliti sebagai kepelbagaian watak, perangai, akal serta fizikal individu yang stabil serta menghasilkan daya tahan dalam menghasilkan keunikan penyesuaian untuk sekeliling. Selain itu, Faizah dan Nagarajan (2012) menyebut personaliti adalah susunan unsur akal dan jiwa yang menentukan perbezaan tingkah laku atau tindakan individu. Konsep personaliti merupakan konsep yang begitu luas sehingga menjadi suatu yang amat penting.

Kajian-kajian lepas menunjukkan bahawa personaliti memberi kesan ke atas individu baik dari segi prestasi, motivasi mahupun kepuasan diri kerana mereka lebih bersedia untuk mengawal persekitarannya. Individu menyesuaikan diri dengan keadaan sekeliling bergantung kepada personaliti mereka yang kemudian menentukan tindakan yang

dilakukan. Kecenderungan memiliki personaliti yang selaras dengan latar belakang kerjaya dapat membantu individu mencapai kestabilan kerja (Sidek, 2008). Barrick dan Mount (1991) menyatakan bahawa ciri personaliti merupakan faktor peramal yang sah dan boleh dipercayai dalam menentukan prestasi individu.

Teori tret personaliti 'big five' diterima pakai dalam semua kajian personaliti yang terlibat dalam kajian psikologi sosial dan telah menghasilkan banyak artikel yang meliputi aspek psikologi, sains pendidikan, teknologi dan pelbagai aspek yang lain. Dalam teori Personaliti 'Big Five', personaliti telah dibahagikan kepada lima dimensi personaliti utama iaitu keterbukaan, kehematan, ekstraversi, kepersetujuan dan neurotisme.

1. Keterbukaan (Openness to experience): Dimensi ini menerangkan keterbukaan kepada pengalaman kognitif dan bukan kognitif, yang ditunjukkan dalam pelbagai kepentingan, kesungguhan untuk mencari dan pengalaman hidup baru dan luar biasa tanpa kebimbangan dan juga dengan keseronokan.

2. Kehematan (Conscientiousness): Merupakan satu dimensi yang menumpukan kepada isu-isu seperti orientasi, tingkah laku kebiasaan, dan kawalan gerak hati. Ia merujuk kepada individu yang bertanggungjawab, berhati-hati, teliti, teratur, boleh dipercayai, rajin, berdisiplin, menepati masa, kemas, bercita-cita tinggi dan gerak hati.

3. Ekstraversi (Extroversion): Individu yang tinggi dalam extraversi digambarkan sebagai tegas, bercita-cita tinggi, pandai bergaul, aktif, suka bercakap, berorientasikan orang, optimistik, dan penyayang. 
4. Kepersetujuan (Agreeableness): Individu yang tinggi dalam kepersetujuan digambarkan sebagai bertolak ansur, mempercayai, fleksibel, pemaaf, bekerjasama, sopan, lembut hati, baik-hati, membantu, mudah tertipu serta terus-terang.

5. Neurotisme (Neuroticism): Neurotisme digambarkan sebagai ketidakstabilan emosi, iaitu meliputi perasaan marah, malu, cemas, bermusuhan, tertekan, sedar diri, impulsif, bimbang, gelisah, emosional, tidak selamat, dan tidak mencukupi.

Banyak kajian telah menggunakan model 'Big Five' untuk mengkaji perhubungan di antara tret personaliti dengan pencapaian akademik pelajar dan kajian ini telah berjaya mengenal pasti kekuatan personaliti 'big five' dalam menilai pencapaian akademik pelajar. Kajian daripada Che Nurul dan Radin (2019) mendapati bahawa tret extraversi, kepersetujuan, kehematan dan keterbukaan telah mendorong kecenderungan keusahawanan pelajar teknik dan vokasional aliran perniagaan. Manakala Novikova dan Vorobyeva (2017) menyatakan bahawa keterbukaan merupakan tret yang paling signifikan dan mempunyai hubungan yang positif dengan pencapaian akademik. Pelajar yang mempunyai tret keterbukaan yang tinggi berupaya untuk mendapat skor yang tinggi dalam semua bidang ini.

Pada pendapat penyelidik, bilangan sebenar kajian yang telah menggunakan pendekatan tret personaliti 'big five' di Malaysia adalah masih kecil berbanding kajian di Negara Barat. Oleh itu, matlamat kajian ini adalah untuk menghasilkan laporan tentang tret personaliti 'big five' yang memberi kesan terhadap prestasi pembelajaran melalui kaedah tinjauan sistematik. Kajian ini juga bertujuan untuk mengetahui tret personaliti manakah yang lebih dominan dan memberi kesan terhadap prestasi pembelajaran.

\section{Metod Kajian}

Kajian ini menggunakan kaedah tinjauan sistematik untuk mengenal pasti tret personaliti 'big five' yang memberi kesan kepada prestasi pembelajaran pelajar. Berdasarkan Kitchenham dan Charters (2007), kajian tinjauan sistematik terbahagi kepada 3 fasa iaitu perancangan tinjauan, menjalankan tinjauan dan melaporkan hasil tinjauan.

\subsection{Kajian Tinjauan Sistematik}

\subsubsection{Perancangan tinjauan}

Langkah pertama untuk menjalankan kajian sistematik adalah menyediakan perancangan dan garis panduan untuk memastikan kajian dapat dijalankan secara teratur. Perancangan tinjauan dimulai dengan menyenaraikan keperluan untuk menjalankan tinjauan, menetapkan matlamat serta persoalan kajian dan membentuk protokol tinjauan untuk mengurangkan bias dalam kajian.

\subsubsection{Menjalankan Tinjauan}

\subsubsection{Strategi carian}

Strategi carian adalah berdasarkan matlamat dan persoalan kajian. Carian ini terhad kepada kajian yang menggunakan reka bentuk kuantitatif dalam bahasa Inggeris serta peer-reviewed jurnal. Berdasarkan Jadual 1, pangkalan data Science Direct telah 
digunakan untuk mencari artikel yang berkaitan dengan menggunakan carian istilah 'tret personaliti', 'personaliti big five' dan 'prestasi pembelajaran' yang dikhususkan pada tahun 2016 sehingga 2021. Carian artikel adalah berdasarkan tajuk kajian yang dipecahkan kepada istilah carian 'tret personaliti', 'personaliti big five' dan 'prestasi pembelajaran'. Untuk mengurangkan hasil carian, artikel yang dipilih hanya dikhususkan kepada artikel yang diterbitkan pada tahun 2016-2021 sahaja.

\section{Jadual 1: Struktur carian}

\section{Pangkalan data akademik Bentuk carian}

Science Direct

Carian tajuk

(carian dalam istilah 'tret personaliti' 'personaliti big five' dan 'prestasi pembelajaran')

\subsubsection{Kriteria pemilihan artikel kajian}

Rajah 1 menunjukkan proses dan kriteria yang telah digunakan dalam pemilihan artikel dalam tinjauan literatur bersistematik.

Rajah 1: Proses pemilihan artikel

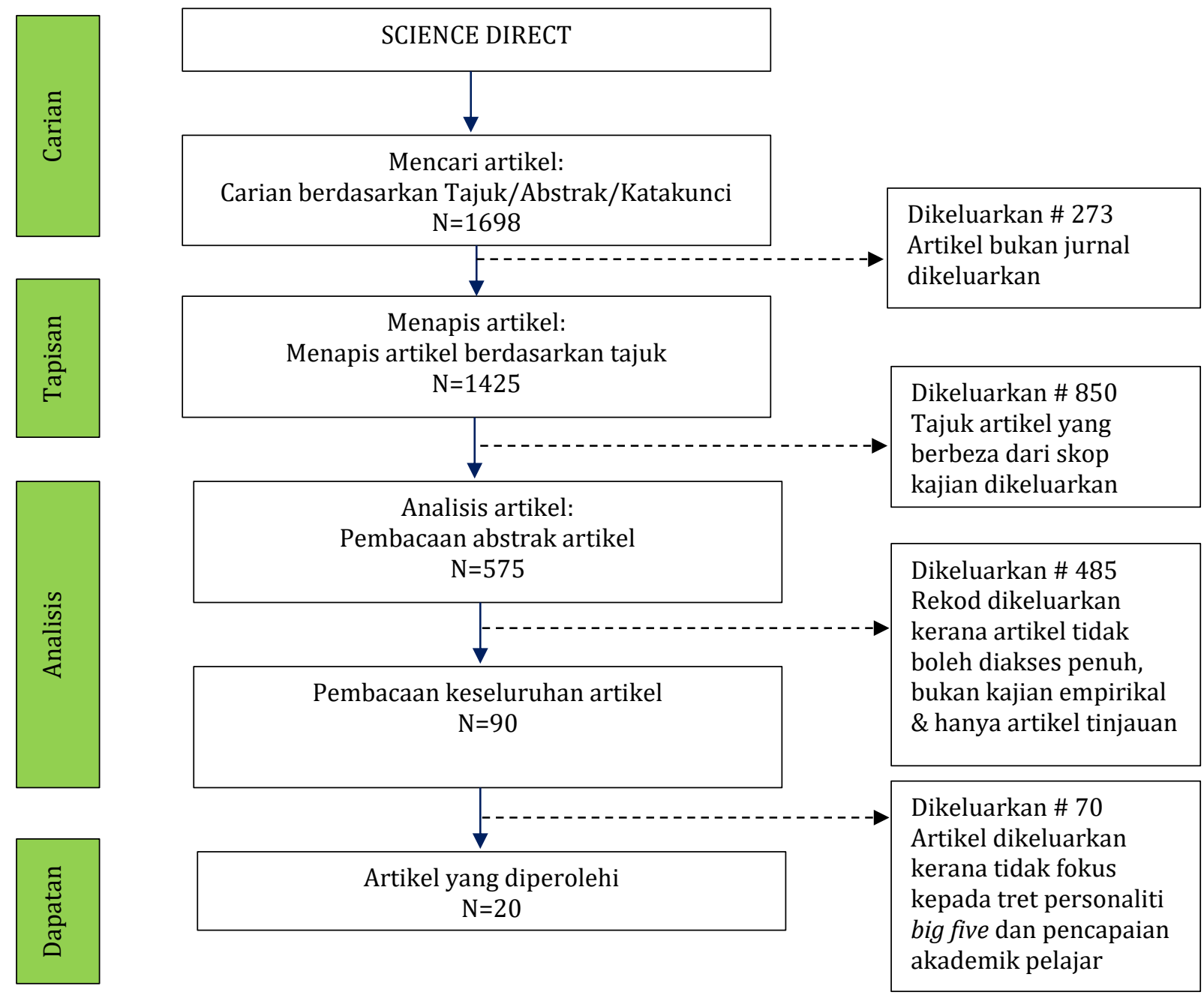

Sumber: Diadaptasi daripada Carrotte dan Anderson (2018) 
Kriteria pemilihan artikel yang diterima untuk kajian ini adalah berdasarkan kepada artikel yang diterbitkan pada tahun 2016 sehingga 2021, artikel yang ditulis dalam Bahasa Melayu atau Bahasa Inggeris, artikel kajian yang melakukan kajian secara kuantitatif, artikel yang membincangkan personal tret atau personaliti 'big five' terhadap prestasi pembelajaran dan artikel yang terdapat dalam prosiding persidangan dan jurnal saintifik. Artikel yang tidak memenuhi kriteria seperti kajian yang tidak empirikal, kajian kedua atau kajian tinjauan, kajian yang masih lagi belum selesai dan artikel pendek dikeluarkan daripada kajian ini. Berdasarkan Rajah 1, sejumlah artikel telah diperoleh melalui enjin carian pangkalan data Science Direct. Hasil carian telah memperoleh sebanyak 1698 carian yang meliputi jenis artikel tinjauan, artikel kajian, bab buku dan abstrak persidangan. Walau bagaimanapun, selepas pembacaan artikel yang menyeluruh, artikel yang tidak memenuhi kriteria telah dikeluarkan dan hanya 20 artikel dipilih kerana memenuhi kriteria yang telah ditetapkan.

\subsubsection{Pengekstrakan Data}

Proses pengekstrakan data dilakukan untuk memperoleh maklumat tentang penulis, tajuk, tahun diterbitkan, nama jurnal, persidangan, objektif kajian, bilangan saiz sampel, jantina, kaedah kajian, jenis personaliti, kaedah pengukuran personaliti dan kesan saiz seperti nilai min dan regresi.

\subsubsection{Karakter artikel/kajian}

Berdasarkan Jadual 2, dua puluh artikel yang dipilih adalah artikel yang diterbitkan dari tahun 2016 sehingga tahun 2021. Semua kajian menggunakan responden lelaki dan perempuan yang berumur dalam lingkungan 14 sehingga 55 tahun. Terdapat beberapa kajian tidak menyatakan bilangan umur bagi responden mereka telah ditandakan dengan X. Sebelas kajian telah menggunakan pelajar universiti sebagai sampel (McCredie \& Kurtz, 2020; Novikova \& Vorobyeva, 2017; Hsiao et al., 2016; Kertechian, 2018; Bonaccio et al., 2016; Stajkovic et al., 2018; Gatzka, 2021; M. Muzamil et al., 2017; Dorrenbacher \& Perels, 2016; Cao \& Meng, 2020; Hendy \& Biderman 2019) dan sembilan kajian lagi telah menggunakan pelajar sekolah menengah sebagai sampel (Zhang \& Ziegler; 2018; Steinmayr \& Kessels; 2017; Papageorgiou et al., 2020; Zhang \& Ziegler, 2016; Soric et al., 2017; Israel et al., 2018; Malykh, 2017; Wojciechowska et al., 2021; Abdul Muhid et al., 2021).

Jadual 2: Ciri-ciri kajian lepas

\begin{tabular}{|c|c|c|c|c|c|}
\hline \multirow[t]{2}{*}{ Penulis } & \multirow{2}{*}{$\begin{array}{c}\text { Bilangan } \\
\text { Sampel }\end{array}$} & \multicolumn{2}{|c|}{ Jantina } & \multirow{2}{*}{$\begin{array}{l}\text { Umur } \\
\text { (Tahun) }\end{array}$} & \multirow[t]{2}{*}{ Populasi } \\
\hline & & Lelaki & Perempuan & & \\
\hline $\begin{array}{l}\text { McCredie \& Kurtz } \\
\text { (2020) }\end{array}$ & 191 & 48 & 143 & $18-19$ & Pelajar universiti \\
\hline $\begin{array}{l}\text { Novikova \& } \\
\text { Vorobyeva (2017) }\end{array}$ & 207 & 41 & 166 & $17-25$ & Pelajar universiti \\
\hline Hsiao et al. (2016) & 136 & 58 & 78 & $18-24$ & Pelajar universiti \\
\hline $\begin{array}{l}\text { Zhang \& Ziegler } \\
\text { (2018) }\end{array}$ & 836 & 430 & 406 & $\mathrm{X}$ & $\begin{array}{l}\text { Pelajar sekolah } \\
\text { menengah }\end{array}$ \\
\hline Kertechian (2018) & 404 & 102 & 302 & $17-52$ & Pelajar universiti \\
\hline $\begin{array}{l}\text { Bonaccio et al. } \\
\text { (2016) }\end{array}$ & 204 & 40 & 164 & $\mathrm{X}$ & Pelajar universiti \\
\hline
\end{tabular}




\begin{tabular}{|c|c|c|c|c|c|}
\hline $\begin{array}{l}\text { Steinmayr \& } \\
\text { Kessels (2017) }\end{array}$ & 236 & 94 & 142 & $\mathrm{X}$ & $\begin{array}{l}\text { Pelajar sekolah } \\
\text { menengah }\end{array}$ \\
\hline $\begin{array}{l}\text { Stajkovic et } \\
\text { al.(2018) }\end{array}$ & 875 & 443 & 432 & $\mathrm{X}$ & Pelajar universiti \\
\hline $\begin{array}{l}\text { Papageorgiou et al. } \\
(2020)\end{array}$ & 1179 & 576 & 603 & $14-18$ & $\begin{array}{l}\text { Pelajar sekolah } \\
\text { menengah }\end{array}$ \\
\hline Gatzka (2021) & 424 & 90 & 334 & $21-23$ & Pelajar universiti \\
\hline $\begin{array}{l}\text { M. Muzamil et al. } \\
\text { (2017) }\end{array}$ & 1165 & 468 & 697 & $20-45$ & Pelajar universiti \\
\hline $\begin{array}{l}\text { Zhang \& Ziegler } \\
\text { (2016) }\end{array}$ & 818 & 394 & 424 & $\mathrm{X}$ & $\begin{array}{l}\text { Pelajar sekolah } \\
\text { menengah }\end{array}$ \\
\hline $\begin{array}{l}\text { Dorrenbacher \& } \\
\text { Perels (2016) }\end{array}$ & 337 & 98 & 239 & $\mathrm{X}$ & Pelajar universiti \\
\hline Soric et al. (2017) & 501 & 160 & 341 & $\mathrm{X}$ & $\begin{array}{l}\text { Pelajar sekolah } \\
\text { menengah }\end{array}$ \\
\hline Israel et al. (2018) & 4355 & 2222 & 2133 & $\mathrm{X}$ & $\begin{array}{l}\text { Pelajar sekolah } \\
\text { menengah }\end{array}$ \\
\hline Cao \& Meng (2020) & 555 & 367 & 188 & $16-29$ & Pelajar universiti \\
\hline $\begin{array}{l}\text { Hendy \& Biderman } \\
\text { (2019) }\end{array}$ & 299 & 185 & 114 & $17-40$ & Pelajar universiti \\
\hline Malykh (2017) & 300 & 152 & 148 & $14-17$ & Sekolah Menengah \\
\hline $\begin{array}{l}\text { Wojciechowska et } \\
\text { al. (2021) }\end{array}$ & 216 & 129 & 87 & $15-17$ & Sekolah Menengah \\
\hline $\begin{array}{l}\text { Abdul Muhid et al. } \\
\text { (2021) }\end{array}$ & 2145 & 1036 & 1109 & $\mathrm{X}$ & Sekolah Menengah \\
\hline
\end{tabular}

\subsubsection{Kaedah pengukuran tret personaliti 'big five'}

Semua kajian telah menggunakan kaedah kuantitatif dan beberapa jenis instrumen yang telah digunakan untuk mengukur pengaruh tret personaliti 'big five' terhadap prestasi pembelajaran pelajar. Instrumen yang digunakan untuk mengukur personaliti 'big five' adalah seperti mana yang terdapat dalam Jadual 3. Kaedah pengukuran yang biasanya digunakan dalam mengukur personaliti 'big five' adalah seperti NEO Five-Factor Inventory (NEO-FFI) (McCredie \& Kurtz, 2020; Novikova, \& Vorobyeva, 2017; Zhang \& Ziegler, 2018; Steinmayr \& Kessels, 2017; Zhang \& Ziegler, 2016), Big Five Inventory (BFI) (Hsiao et al., 2016; Papageorgiou et al., 2020; M. Muzamil et al., 2017; Dorrenbacher \& Perels, 2016; Israel et al., 2018; Abdul Muhid et al., 2021), International Personality Item Pool (IPIP) (Bonaccio et al., 2016; Stajkovic et al., 2018; Soric et al., 2017; Hendy \& Biderman, 2019; Wojciechowska et al., 2021), Five-factor model of personality (FFM) (Kertechian, 2018), Big Five Aspect Scales (BFAS) (Gatzka, 2021) dan Chinese Big Five Personality Inventory-Brief Version (CBF-PI-B) (Cao \& Meng, 2020).

Jadual 3: Kaedah pengukuran dan faktor personaliti 'big five' dalam kajian lepas

\begin{tabular}{lll}
\hline Kajian/Penulis & Kaedah Pengukuran & Faktor Personaliti \\
\hline $\begin{array}{l}\text { McCredie \& Kurtz } \\
(2020)\end{array}$ & $\begin{array}{l}\text { NEO Five-Factor Inventory } \\
\text { (NEO-FFI) }\end{array}$ & $\begin{array}{l}\text { Neuroticism, Extraversion, } \\
\text { Openness, Agreeableness, } \\
\text { Conscientiousness }\end{array}$ \\
$\begin{array}{l}\text { Novikova \& Vorobyeva } \\
(2017)\end{array}$ & $\begin{array}{l}\text { NEO Five-Factor Inventory } \\
\text { (NEO-FFI) }\end{array}$ & $\begin{array}{l}\text { Neuroticism, Extraversion, } \\
\text { Openness, Agreeableness, } \\
\text { Conscientiousness }\end{array}$ \\
\hline
\end{tabular}




\begin{tabular}{|c|c|c|}
\hline Hsiao et al. (2016) & $\begin{array}{l}\text { Big Five Inventory } \\
\text { (BFI) }\end{array}$ & $\begin{array}{l}\text { Neuroticism, Extraversion, } \\
\text { Openness, Agreeableness, } \\
\text { Conscientiousness }\end{array}$ \\
\hline Zhang \& Ziegler (2018) & $\begin{array}{l}\text { NEO Five-Factor inventory } \\
\text { (NEO-FFI) }\end{array}$ & $\begin{array}{l}\text { Neuroticism, Extraversion, } \\
\text { Openness, Agreeableness, } \\
\text { Conscientiousness }\end{array}$ \\
\hline Kertechian (2018) & $\begin{array}{l}\text { Five-factor model of } \\
\text { personality (FFM) }\end{array}$ & $\begin{array}{l}\text { Neuroticism, Extraversion, } \\
\text { Openness, Agreeableness, } \\
\text { Conscientiousness }\end{array}$ \\
\hline Bonaccio et al. (2016) & $\begin{array}{l}\text { International Personality Item } \\
\text { Pool (IPIP) }\end{array}$ & $\begin{array}{l}\text { Emotional stability, Extraversion, } \\
\text { Openness, Agreeableness, } \\
\text { Conscientiousness }\end{array}$ \\
\hline $\begin{array}{l}\text { Steinmayr \& Kessels } \\
\text { (2017) }\end{array}$ & $\begin{array}{l}\text { NEO Five-Factor Inventory } \\
\text { (NEO-FFI) }\end{array}$ & $\begin{array}{l}\text { Neuroticism, Extraversion, } \\
\text { Openness, Agreeableness, } \\
\text { Conscientiousness }\end{array}$ \\
\hline Stajkovic et al. (2018) & $\begin{array}{l}\text { International Personality Item } \\
\text { Pool (IPIP) }\end{array}$ & $\begin{array}{l}\text { Emotional stability, Extraversion, } \\
\text { Openness, Agreeableness, } \\
\text { Conscientiousness }\end{array}$ \\
\hline $\begin{array}{l}\text { Papageorgiou et al. } \\
(2020)\end{array}$ & $\begin{array}{l}\text { Big Five Inventory } \\
\text { (BFI) }\end{array}$ & $\begin{array}{l}\text { Neuroticism, Extraversion, } \\
\text { Openness, Agreeableness, } \\
\text { Conscientiousness }\end{array}$ \\
\hline Gatzka (2021) & Big Five Aspect Scales (BFAS) & Openness, Conscientiousness \\
\hline M. Muzamil et al. (2017) & $\begin{array}{l}\text { Big Five Inventory } \\
\text { (BFI) }\end{array}$ & $\begin{array}{l}\text { Emotional stability, Extraversion, } \\
\text { Openness, Agreeableness, } \\
\text { Conscientiousness }\end{array}$ \\
\hline Zhang \& Ziegler (2016) & $\begin{array}{l}\text { NEO Five-Factor Inventory } \\
\text { (NEO-FFI) }\end{array}$ & $\begin{array}{l}\text { Neuroticism, Extraversion, } \\
\text { Openness, Agreeableness, } \\
\text { Conscientiousness }\end{array}$ \\
\hline $\begin{array}{l}\text { Dorrenbacher \& Perels } \\
\text { (2016) }\end{array}$ & $\begin{array}{l}\text { Big Five Inventory } \\
\text { (BFI) }\end{array}$ & $\begin{array}{l}\text { Neuroticism, Extraversion, } \\
\text { Openness, Agreeableness, } \\
\text { Conscientiousness }\end{array}$ \\
\hline Soric et al. (2017) & $\begin{array}{l}\text { International Personality Item } \\
\text { Pool (IPIP) }\end{array}$ & $\begin{array}{l}\text { Extraversion, Agreeableness, } \\
\text { Conscientiousness, Emotional } \\
\text { Stability (Neuroticism), Intellect } \\
\text { (Openness) }\end{array}$ \\
\hline Israel et al. (2018) & $\begin{array}{l}\text { Big Five Inventory } \\
\text { (BFI) }\end{array}$ & $\begin{array}{l}\text { Neuroticism, Extraversion, } \\
\text { Openness, Agreeableness, } \\
\text { Conscientiousness }\end{array}$ \\
\hline Cao \& Meng (2020) & $\begin{array}{l}\text { Chinese Big Five Personality } \\
\text { Inventory-Brief Version (CBF- } \\
\text { PI-B) }\end{array}$ & $\begin{array}{l}\text { Neuroticism, Extraversion, } \\
\text { Openness, Agreeableness, } \\
\text { Conscientiousness }\end{array}$ \\
\hline $\begin{array}{l}\text { Hendy \& Biderman } \\
\text { (2019) }\end{array}$ & $\begin{array}{l}\text { International Personality Item } \\
\text { Pool (IPIP) }\end{array}$ & Extraversion, Conscientiousness \\
\hline Malykh (2017) & $N E O-P I-R$ & $\begin{array}{l}\text { Neuroticism, Extraversion, } \\
\text { Openness, Agreeableness, } \\
\text { Conscientiousness }\end{array}$ \\
\hline $\begin{array}{l}\text { Wojciechowska et al. } \\
\text { (2021) }\end{array}$ & $\begin{array}{l}\text { International Personality Item } \\
\text { Pool (IPIP) }\end{array}$ & $\begin{array}{l}\text { Neuroticism, Extraversion, } \\
\text { Intellect, Agreeableness, } \\
\text { Conscientiousness }\end{array}$ \\
\hline $\begin{array}{l}\text { Abdul Muhid et al. } \\
\text { (2021) }\end{array}$ & Big Five Inventory (BFI) & $\begin{array}{l}\text { Neuroticism, Extraversion, } \\
\text { Openness, Agreeableness, } \\
\text { Conscientiousness }\end{array}$ \\
\hline
\end{tabular}




\section{Hasil Kajian}

\subsection{Pengaruh Tret Personaliti Big Five}

Ramai penyelidik telah menggunakan tret personaliti 'big five' untuk mengkaji tingkah laku manusia kerana tret menjadikan seseorang itu berbeza tingkah laku dalam pelbagai situasi. Jadual 4 menunjukkan hasil kajian yang diperoleh daripada artikel kajian yang dipilih. Berdasarkan analisis terhadap artikel ini, kehematan dan keterbukaan merupakan tret personaliti yang paling mempengaruhi pencapaian akademik pelajar.

Jadual 4: Kesan tret personaliti 'big five' terhadap pencapaian akademik

\begin{tabular}{|c|c|c|}
\hline \multirow[t]{2}{*}{ Kajian/Penulis } & \multicolumn{2}{|c|}{ Tret Personaliti } \\
\hline & Kesan Positif & Kesan Negatif \\
\hline McCredie \& Kurtz (2020) & Kehematan & $\begin{array}{l}\text { Neurotisme, Extraversi, } \\
\text { Keterbukaan, Kepersetujuan }\end{array}$ \\
\hline $\begin{array}{l}\text { Novikova \& Vorobyeva } \\
\text { (2017) }\end{array}$ & $\begin{array}{l}\text { Kehematan, Extraversi, } \\
\text { Keterbukaan }\end{array}$ & Neurotisme, Kepersetujuan \\
\hline Hsiao et al. (2016) & Kehematan & $\begin{array}{l}\text { Extraversi, Keterbukaan, } \\
\text { Kepersetujuan, Neurotisme }\end{array}$ \\
\hline Zhang \& Ziegler (2018) & Keterbukaan, Kehematan & $\begin{array}{l}\text { Neurotisme, Extraversi, } \\
\text { Kepersetujuan }\end{array}$ \\
\hline Kertechian (2018) & Kehematan & $\begin{array}{l}\text { Neurotisme, Extraversi, } \\
\text { Keterbukaan, Kepersetujuan }\end{array}$ \\
\hline Bonaccio et al. (2016) & Kepersetujuan & $\begin{array}{l}\text { Neurotisme, Extraversi, } \\
\text { Keterbukaan, Kehematan }\end{array}$ \\
\hline $\begin{array}{l}\text { Steinmayr \& Kessels } \\
\text { (2017) }\end{array}$ & $\begin{array}{l}\text { Kepersetujuan, Keterbukaan, } \\
\text { Kehematan }\end{array}$ & Neurotisme, Extraversi \\
\hline Stajkovic et al. (2018) & Kehematan & $\begin{array}{l}\text { Neurotisme, Extraversi, } \\
\text { Keterbukaan, Kepersetujuan }\end{array}$ \\
\hline Papageorgiou et al. (2020) & $\begin{array}{l}\text { Kehematan, Keterbukaan, } \\
\text { Kepersetujuan, Neurotisme }\end{array}$ & Extraversi \\
\hline Gatzka (2021) & Kehematan, Keterbukaan & \\
\hline M. Muzamil et al. (2017) & $\begin{array}{l}\text { Neurotisme, Kepersetujuan } \\
\text { Keterbukaan, Kehematan, } \\
\text { Extraversi }\end{array}$ & \\
\hline Zhang \& Ziegler (2016) & $\begin{array}{l}\text { Keterbukaan, Kehematan, } \\
\text { Extraversi }\end{array}$ & Neurotisme, Kepersetujuan \\
\hline $\begin{array}{l}\text { Dorrenbacher \& Perels } \\
\text { (2016) }\end{array}$ & Kehematan & $\begin{array}{l}\text { Neurotisme, Extraversi, } \\
\text { Keterbukaan, Kepersetujuan }\end{array}$ \\
\hline Soric et al. (2017) & Kehematan & $\begin{array}{l}\text { Neurotisme, Extraversi, } \\
\text { Keterbukaan, Kepersetujuan }\end{array}$ \\
\hline Israel et al. (2018) & $\begin{array}{l}\text { Keterbukaan, Kehematan, } \\
\text { Extraversion, Kepersetujuan }\end{array}$ & Neurotisme \\
\hline Cao \& Meng (2020) & $\begin{array}{l}\text { Keterbukaan, Kehematan, } \\
\text { Extraversion, Kepersetujuan }\end{array}$ & Neurotisme \\
\hline Hendy \& Biderman (2019) & Kehematan & \\
\hline Malykh (2017) & Kehematan, Keterbukaan & $\begin{array}{l}\text { Neurotisme, Kepersetujuan } \\
\text { Extraversi }\end{array}$ \\
\hline $\begin{array}{l}\text { Wojciechowska et al. } \\
\text { (2021) } \\
\text { Abdul Muhid et al. (2021) }\end{array}$ & Kehematan & $\begin{array}{l}\text { Neurotisme, Extraversi, } \\
\text { Keterbukaan, Kepersetujuan } \\
\text { Neurotisme, Extraversi, } \\
\text { Keterbukaan, Kepersetujuan, } \\
\text { Kehematan }\end{array}$ \\
\hline
\end{tabular}


Rajah 2 menunjukkan bahawa kehematan merupakan tret personaliti yang paling mempengaruhi prestasi akademik pelajar iaitu sebanyak 18 kajian dan diikuti dengan tret keterbukaan iaitu sebanyak 10 kajian. Manakala bagi tret kepersetujuan, extraversi dan neutralisme masing-masing sebanyak 6, 5 dan 2 kajian. Sebanyak 15 kajian menyatakan bahawa personaliti neurotisme merupakan personaliti yang paling tidak mempengaruhi prestasi akademik pelajar diikuti dengan personaliti extraversi (14), kepersetujuan (12), keterbukaan (9) dan kehematan (2).

Rajah 2: Pengaruh personaliti 'big five’ terhadap pencapaian akademik pelajar

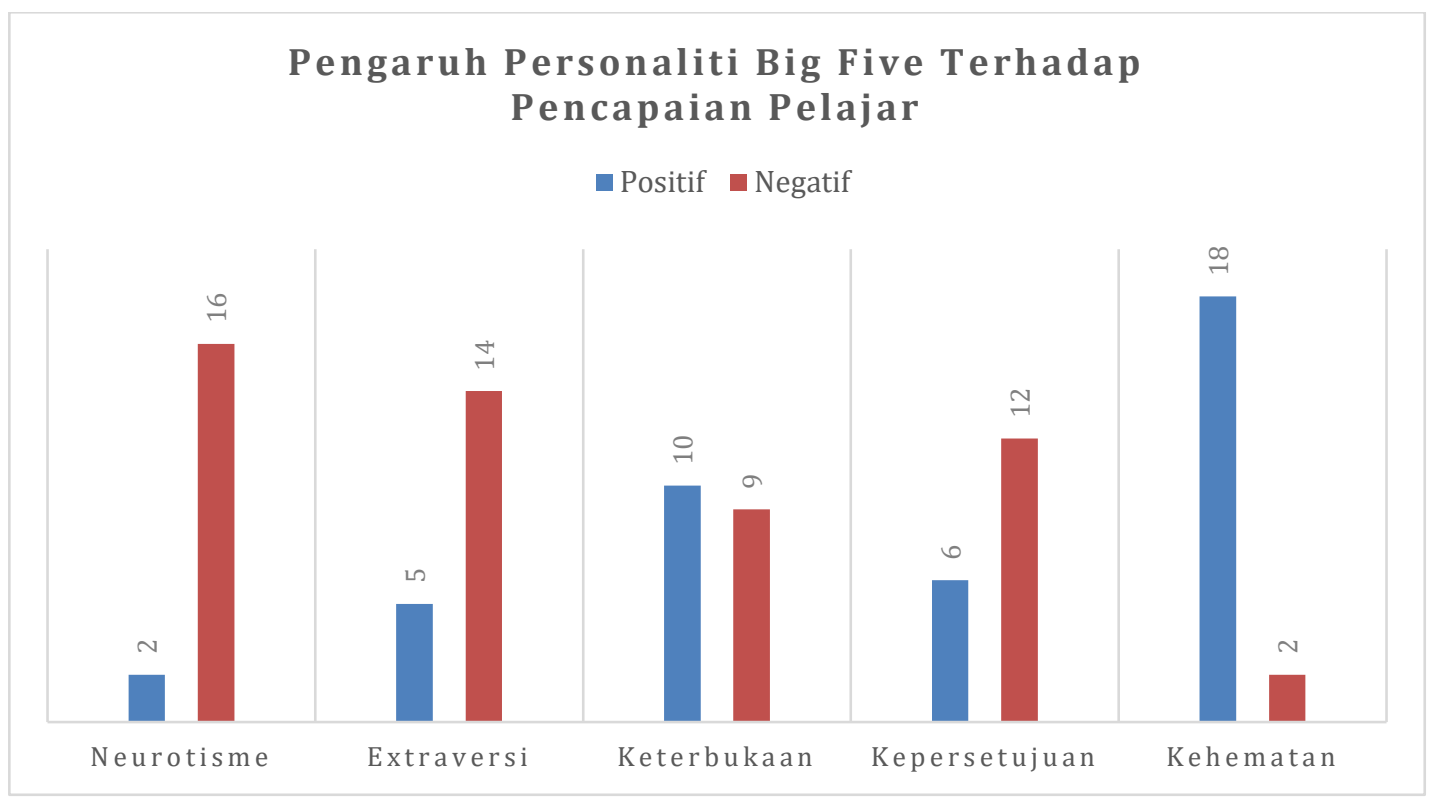

\subsubsection{Kehematan (Conscientiousness)}

Kehematan merupakan tret personaliti yang paling mempengaruhi prestasi akademik pelajar berbanding tret yang lain (Soric et al., 2017). Tret personaliti kehematan memberi implikasi yang besar dan mampu menjadi peramal yang signifikan berbanding faktor personaliti lain (Mas Ayu \& Fatimahwati, 2013). Berdasarkan 20 artikel kajian yang dipilih, kehematan merupakan tret yang paling signifikan dan mempunyai hubungan yang positif dengan pencapaian akademik (McCredie \& Kurtz, 2020; Novikova \& Vorobyeva, 2017; Hsiao et al., 2016; Zhang \& Ziegler (2018); Kertechian, 2018; Steinmayr \& Kessels, 2017; Stajkovic et al., 2018; Gatzka, 2021; M. Muzamil et al., 2017; Zhang \& Ziegler, 2016; Dorrenbacher \& Perels, 2016; Soric et al., 2017; Israel et al., 2018; Cao \& Meng, 2020; Hendy \& Biderman, 2019; Malykh, 2017; Wojciechowska et al., 2021; Papageorgiou et al., 2020).

Kajian daripada Novikova dan Vorobyeva (2017) menunjukkan bahawa pelajar yang mempunyai tret kehematan yang tinggi berupaya untuk mendapat skor yang lebih tinggi dalam semua subjek yang dikaji. Zhang dan Ziegler (2018) juga menemui pelajar yang mempunyai tret kehematan yang tinggi berjaya meningkatkan prestasi akademik kerana mereka cenderung kepada pembelajaran secara mendalam (deep learning) berbanding pembelajaran secara hafalan sahaja (surface learning).

Pencapaian pelajar dipengaruhi secara langsung oleh tret kehematan dan juga secara tidak langsung melalui pengantara keyakinan diri (Stajkovic et al., 2018). Pelajar yang 
mempunyai tret kehematan yang tinggi lebih bermotivasi untuk memahami apa yang mereka belajar. Oleh itu, pembelajaran secara mendalam menjadi pengantara yang mempengaruhi tret kehematan terhadap markah Matematik (Zhang \& Ziegler, 2016). Hanya 2 artikel kajian menemui bahawa kehematan tidak mempengaruhi prestasi akademik pelajar (Abdul Muhid et al., 2021; Bonaccio et al., 2016). Walaupun kehematan memberi kesan positif terhadap persepsi akademik tetapi ia tidak memberi kesan yang positif terhadap gred kursus.

\subsubsection{Keterbukaan (Openness to experience)}

Daripada 20 artikel yang dipilih, 10 artikel mendapati tret keterbukaan mempunyai hubungan yang positif dengan pencapaian akademik (Novikova \& Vorobyeva, 2017; Zhang \& Ziegler (2018); Papageorgiou et al., 2020; Steinmayr \& Kessels, 2017; Gatzka, 2021; M. Muzamil et al., 2017; Zhang \& Ziegler, 2016; Israel et al., 2018; Cao \& Meng, 2020; Malykh, 2017). Pelajar yang mempunyai tret keterbukaan yang tinggi lebih bermotivasi untuk memahami apa yang mereka belajar. Oleh itu, tret keterbukaan telah mempengaruhi semua markah yang diperoleh oleh pelajar dalam ketiga-tiga subjek (Matematik, Inggeris, Bahasa Cina) yang dikaji (Zhang \& Ziegler, 2016). Tetapi, apabila penulis memasukkan pembelajaran secara mendalam sebagai pengantara antara tret keterbukaan dan markah subjek matematik, Inggeris dan Bahasa Cina. Hasil yang diperoleh adalah berlainan. Pembelajaran secara mendalam hanya memberi kesan sebagai pengantara antara tret keterbukaan dengan markah Matematik dan Bahasa Cina sahaja, tetapi tidak memberi kesan kepada markah Bahasa Inggeris. Sama dengan hasil kajian daripada (Novikova \& Vorobyeva, 2017), pelajar yang mempunyai tret keterbukaan yang tinggi hanya mempunyai hubungan yang positif dengan pencapaian dalam subjek Bahasa Asing Kedua sahaja dan tidak mempunyai hubungan yang positif dengan subjek lain.

Walau bagaimanapun, Sembilan artikel yang dipilih mendapati bahawa tret personaliti keterbukaan tidak mempengaruhi prestasi akademik pelajar (McCredie \& Kurtz, 2020; Hsiao et al., 2016; Kertechian, 2018; Bonaccio et al., 2016; Stajkovic et al., 2018; Dorrenbacher \& Perels, 2016; Soric et al., 2017; Wojciechowska et al., 2021; Abdul Muhid et al., 2021). Hanya satu sahaja artikel yang tidak mengkaji pengaruh personaliti keterbukaan terhadap prestasi pelajar.

\subsubsection{Ekstraversi (Extraversion)}

Sebanyak empat belas artikel kajian yang menemui bahawa tret personaliti ekstraversi tidak mempengaruhi prestasi akademik pelajar akademik pelajar (McCredie \& Kurtz, 2020; Hsiao et al., 2016; Zhang \& Ziegler, 2018; Kertechian, 2018; Bonaccio et al., 2016; Steinmayr \& Kessels, 2017; Stajkovic et al., 2018; Gatzka, 2021; Dorrenbacher \& Perels, 2016; Soric et al., 2017; Malykh, 2017; Wojciechowska et al., 2021; Papageorgiou et al., 2020; Abdul Muhid et al., 2021; Hendy \& Biderman, 2019). Individu yang mempunyai tret ekstraversi di gambarkan sebagai individu yang tegas, bercita-cita tinggi, pandai bergaul, aktif, suka bercakap, berorientasikan orang, optimistik, dan penyayang. Novikova dan Vorobyeva (2017) mendapati bahawa pelajar yang mempunyai tret extraversi yang tinggi, mempunyai hubungan yang positif dengan pencapaian dalam subjek Bahasa Asing Kedua dan 'Special Disciplines' sahaja dan tidak memberi kesan yang positif kepada subjek Bahasa Inggeris. 
Hanya lima artikel kajian yang dipilih menyatakan bahawa tret personaliti ekstraversi mempengaruhi prestasi akademik pelajar akademik (Novikova \& Vorobyeva, 2017; M. Muzamil et al., 2017; Zhang \& Ziegler, 2016; Israel et al., 2018; Cao \& Meng, 2020). Terdapat satu artikel kajian iaitu kajian daripada Hendy dan Biderman (2019) tidak mengkaji pengaruh tret ekstraversi terhadap pencapaian akademik pelajar.

\subsubsection{Kepersetujuan (Agreeableness)}

Sebanyak 12 artikel kajian yang dipilih menyatakan bahawa tret personaliti kepersetujuan tidak mempengaruhi prestasi akademik pelajar akademik (McCredie \& Kurtz, 2020; Hsiao et al., 2016; Novikova \& Vorobyeva, 2017; Zhang \& Ziegler, 2018; Kertechian, 2018; Stajkovic et al., 2018; Dorrenbacher \& Perels, 2016; Soric et al., 2017; Zhang \& Ziegler, 2016; Malykh, 2017; Wojciechowska et al., 2021; Abdul Muhid et al., 2021). Ini bermaksud, pelajar yang mempunyai tret kepersetujuan yang tinggi akan memperoleh pencapaian akademik yang rendah.

Manakala 6 artikel kajian menyatakan bahawa tret personaliti kepersetujuan telah mempengaruhi prestasi akademik pelajar (M. Muzamil et al., 2017; Israel et al., 2018; Cao \& Meng, 2020; Bonaccio et al., 2016; Steinmayr \& Kessels, 2017; Papageorgiou et al., 2020). Kajian daripada Abdul Muhid et al. (2021) telah menunjukkan bahawa pelajar yang mempunyai tret personaliti kepersetujuan telah mempengaruhi pencapaian markah kesemua subjek (Matematik, Sains, Pengajian Islam, Inggeris) kecuali bagi subjek Bahasa Arab. Dua artikel lagi, iaitu kajian daripada Gatzka (2021) serta Hendy dan Biderman (2019) tidak mengkaji pengaruh tret kepersetujuan terhadap prestasi akademik pelajar.

\subsubsection{Neurotisme (Neuroticism)}

Dalam kajian ini, neurotisme merupakan tret yang paling tidak mempengaruhi pencapaian akademik (McCredie \& Kurtz, 2020; Novikova \& Vorobyeva, 2017; Hsiao et al., 2016; Zhang \& Ziegler (2018); Kertechian, 2018; Bonaccio et al., 2016; Zhang \& Ziegler, 2016; Dorrenbacher \& Perels, 2016; Soric et al., 2017; Israel et al., 2018; Cao \& Meng, 2020; Malykh, 2017; Wojciechowska et al., 2021; Abdul Muhid et al., 2021; Stajkovic et al., 2018; Steinmayr \& Kessels, 2017). Novikova dan Vorobyeva (2017) menyatakan bahawa pelajar yang mempunyai tret neurotisme mempunyai hubungan yang bertentangan dengan pencapaian akademik. Oleh itu, pelajar yang mempunyai tret ini cenderung mendapat markah yang rendah.

Walau bagaimanapun, dua artikel kajian menemui bahawa tret personaliti neurotisme mempengaruhi pencapaian akademik pelajar (Papageorgiou et al., 2020; M. Muzamil et al., 2017). M. Muzamil et al. (2017) menyatakan bahawa tret neurotisme merupakan tret yang paling signifikan mempengaruhi pencapaian pelajar berbanding tret yang lain. Ini terbukti apabila tret neurotisme telah mempengaruhi pencapaian markah kesemua subjek yang dikaji iaitu Bahasa Arab, Pengajian Islam, Inggeris, Sains dan Matematik. Oleh itu, pelajar yang mempunyai tret neorotisme mempunyai kecenderungan untuk mempunyai pencapaian akademik yang tinggi. Manakala 2 artikel iaitu kajian daripada Gatzka (2021) serta Hendy dan Biderman (2019) tidak mengkaji kesan tret neurotisme terhadap prestasi akademik pelajar. 


\section{Perbincangan Kajian}

Tujuan kajian ini dijalankan adalah untuk melakukan tinjauan secara sistematik terhadap kajian yang mengkaji perhubungan antara tret personaliti 'big five' dan pencapaian akademik pelajar. Sebanyak 20 artikel kajian yang menepati kriteria yang ditetapkan telah dipilih untuk memeriksa perhubungan antara tret personaliti 'big five' terhadap pencapaian akademik pelajar. Melalui kajian yang telah dijalankan, terdapat beberapa bukti yang konsisten untuk mengaitkan pengaruh tret personaliti 'big five' terhadap pencapaian pelajar.

Bukti yang paling konsisten yang menghubungkan tret personaliti 'big five' dan pencapaian akademik pelajar yang ditemui adalah tret kehematan. Ini boleh dijelaskan melalui bukti bahawa pelajar yang mempunyai tret kehematan yang tinggi lebih cenderung untuk belajar bersungguh-sungguh untuk mendapat markah yang tinggi. Kehematan merupakan tret yang paling dominan berbanding tret yang lain dan mempunyai hubungan yang positif dengan pencapaian akademik pelajar (Novikova \& Vorobyeva, 2017).

Walau bagaimanapun, dua kajian telah menemui bahawa kehematan tidak mempengaruhi pencapaian akademik pelajar (Abdul Muhid et al., 2021; Bonaccio et al., 2016). Kajian daripada Abdul Muhid et al. (2021) telah menunjukkan hasil kajian yang pelbagai apabila pelajar yang mempunyai tret personaliti kepersetujuan telah mempengaruhi pencapaian markah kesemua subjek (Matematik, Sains, Pengajian Islam, Inggeris) kecuali bagi subjek Bahasa Arab.

Dalam kajian ini, tret neurotisme merupakan tret yang paling tidak mempengaruhi pencapaian akademik pelajar. Ini dibuktikan apabila enam belas artikel yang dianalisis telah menunjukkan bahawa tret neurotisme tidak mempengaruhi pencapaian akademik pelajar. Oleh itu, pelajar yang mempunyai tret neurotisme yang tinggi dikatakan akan memperoleh pencapaian akademik yang rendah. Walau bagaimanapun, hasil kajian daripada Abdul Muhid et al. (2021) telah memberikan hasil kajian yang berbeza apabila beliau menemui bahawa tret neurotisme merupakan tret yang paling signifikan mempengaruhi pencapaian pelajar berbanding tret yang lain. Ini terbukti apabila tret neurotisme telah mempengaruhi kesemua pencapaian markah subjek yang dikaji iaitu Bahasa Arab, Pengajian Islam, Inggeris, Sains dan Matematik.

Walau bagaimanapun, tret personaliti yang lain telah menunjukkan kesan yang berbezabeza bagi setiap subjek. Contohnya, tret ekstraversi dan kepersetujuan telah mempengaruhi pencapaian markah subjek Bahasa Arab dan Pengajian Islam tetapi pada masa yang sama tidak mempengaruhi pencapaian markah subjek Matematik, Inggeris dan Sains. Tret Keterbukaan pula menunjukkan kesan yang positif terhadap markah subjek Matematik, Pengajian Islam, Inggeris dan Sains tetapi tidak memberi kesan kepada markah subjek Bahasa Arab.

\section{Kesimpulan}

Berdasarkan penjelasan di atas, boleh disimpulkan bahawa semua tret personaliti 'big five' iaitu neorotisme, keterbukaan, kehematan, kepersetujuan dan ekstraversi memberi kesan yang berbeza kepada pencapaian akademik pelajar. Tret kehematan dan keterbukaan merupakan tret yang paling mempengaruhi pencapaian akademik pelajar berbanding tret personaliti yang lain. Ini bermakna, pelajar yang mempunyai tret 
kehematan dan keterbukaan yang baik dijangkakan dapat meningkatkan pencapaian akademik mereka dalam semua subjek. Manakala tret neurotisme merupakan tret yang paling tidak mempengaruhi pencapaian akademik pelajar berbanding tret personaliti yang lain. Ini bermaksud, pelajar yang mempunyai tret neurotisme yang tinggi dijangkakan tidak dapat meningkatkan pencapaian markah dalam semua subjek.

Terdapat beberapa batasan dalam kajian ini. Salah satu cabaran besar dalam menjalankan kajian ini adalah skop kajian telah disempitkan hanya kepada 20 artikel sahaja dan tertumpu kepada pengaruh tret personaliti 'big five' terhadap pencapaian akademik sahaja. Oleh itu, faktor personaliti lain tidak boleh diukur. Selain itu, penggunaan instrumen pengukuran yang berbeza juga merupakan salah satu limitasi dalam kajian ini kerana ia boleh menjadikan hasil perbandingan yang bermasalah kerana kesahihan setiap konstruktif yang berbeza. Artikel kajian yang diperoleh dari luar Negara juga mungkin berbeza untuk disamakan dengan situasi pelajar di Malaysia.

Semoga dapatan kajian dapat dijadikan panduan dan rujukan kepada guru-guru dan pensyarah untuk memberi lebih perhatian kepada tret kehematan dan keterbukaan sebagai peramal kepada pencapaian akademik pelajar. Walau bagaimanapun, satu kajian yang lebih terperinci perlu dilakukan pada masa hadapan untuk mengetahui mengapakah tret yang sama memberikan kesan yang berbeza kepada subjek yang dipelajari oleh pelajar.

\section{Penghargaan (Acknowledgement)}

Terima kasih diucapkan kepada penyelia kajian ini iaitu Dr. Shahlan bin Surat dan juga kepada rakan-rakan seperjuangan.

\section{Kewangan (Funding)}

Kajian dan penerbitan ini idak menerima sebarang tajaan atau bantuan kewangan.

\section{Konflik Kepentingan (Conflict of Interests)}

Penulis tidak mempunyai sebarang konflik kepentingan dalam kajian dan penerbitan ini.

\section{Rujukan}

Abd Rahman Azilah (2010). Hubungan antara personaliti dan gaya pengajaran guru dengan pencapaian matematik PMR satu kajian di sekolah menengah daerah kota tinggi. Masters thesis, Universiti Teknologi Malaysia.

Abdul Muhid et al. (2021). Big Five Personality Test for State Islamic Senior High School Students in Indonesia. International Journal of Instruction, 14(2), 483-500.

Allen, M. S., \& Walter, E. E. (2018). Linking big five personality trets to sexuality and sexual health: A meta-analytic review. Psychological bulletin, 144(10), 1081.

Barrick, M. R., \& Mount, M. K. (1991). The Big Five Personality Dimensions and Job Performance: A Meta-Analysis. Personnel Psychology, 44, 1-26.

Bonaccio S., Reeve, C. L. \& Lyerly, J. (2016). Academic entitlement: Its personality and general mental ability correlates, and academic consequences. Personality and Individual Differences, 102, 211-216. 
Cao, C. \& Meng, (2020). Exploring personality trets as predictors of English achievement and global competence among Chinese university students: English learning motivation as the moderator. Learning and Individual Differences, 77(20), 101814.

Carrotte, E. \& Anderson, J. R. (2018). A systematic review of the relationship between trait self-objectification and personality traits. Personality and Individual Differences, 132(2018), 20-31.

Che Nurul Kamilah, Radin Siti Aishah (2019). Tret personality (extraversion, agreeableness, conscientiousness, dan openness) mendorong kecenderungan keusahawanan pelajar teknik dan vokasional. Satu kajian di Kolej Vokasional Daerah Kuala Terengganu. Journal of Global Business and Social Entrepreneurship, 5(15), 3545.

Dorrenbacher, L \& Perels, F. (2016). Self-regulated learning profiles in college students: Their relationship to achievement, personality, and the effectiveness of an intervention to foster self-regulated learning. Learning and Individual Differences, $51,229-241$.

Faizah Abd Ghani \& Nagarajan Kupusamy (2012). Hubungan tret personaliti dan kecekapan guru bimbingan dan kaunseling dalam pelaksanaan perkhidmatan bimbingan dan kaunseling di sekolah menengah daerah Pasir Gudang, Johor. Journal of Educational Psychology \& Counseling, 6.

Gatzka. (2021). Aspects of openness as predictors of academic achievement. Personality and Individual Differences, 170, 1104112.

Hendy, N. T. \& Biderman, M. D (2019). Using bifactor model of personality to predict academic performance and dishonesty. The International Journal of Management Education. 17, 294-303.

Hsiao, K. L., Yu Shu \& Huang T. C. (2016).Exploring the effect of compulsive social app usage on technostress and academic performance: Perspectives from personality trets. Telematic and Informatics, 34, 679-690.

Israel, A., Ludke, O. \& Wagner, J. (2018). The longitudinal association between personality and achievement in adolescence: Differential effects across all Big Five trets and four achievement indicators. Learning and Individual Differences, 72, 80-91.

Kertechian, S. K. (2018). Conscientiousness as a key to success for academic achievement among French university students enrolled in management studies. The International Journal of Management Education, 16, 154-165.

Kitchenham, B. \& Charters, S. (2007). Guidelines for performing systematic literature reviews in software engineering version. Engineering, 45, 1051.

M. Muzamil et al. (2017). Facebook or to Face Book? An investigation of how academic performance of different personalities is affected through the intervention of Facebook usage. Computers in Human Behavior, 75, 167-176.

Malykh, S. (2017). The role of personality trets and intelligence in academic achievement of Russian high school students. Procedia-Social and Behavioral Sciences, 237, 13041309.

Mas Ayu Othman, \& Fatimahwati Halim (2013). Pengaruh Personaliti Lima Faktor Terhadap Prestasi Kerja Dalam Kalangan Guru. Jurnal Psikologi dan Kaunseling, 4.

McCredie, M. N. \& Kurtz, J. F. (2020). Prospective prediction of academic performance in college using self- and informant-rated personality trets. Journal of Research in Personality, 85.

Norhaiza Tahir (2015). Hubungan Personaliti Guru Terhadap Kemahiran Proses Sains Pelajar. Masters thesis, Universiti Tun Hussein Onn Malaysia, Fakulti Pendidikan Teknik Dan Vakasional.

Novikova, I. A. \& Vorobyeva, A. A. (2017). Big Five factors and academic achievement in Russian students. Psychology in Russia: State of the Art, 10(4). 
Papageorgiou, K. A., Likhanov, M., Costantini, G., Tsigeman, E., Zaleshin, M., Budakova, A. \& Kovas, Y. (2020). Personality, Behavioral strengths and difficulties and performance of adolescents with high achievements in science, literature, art and sports. Personality and Individual Differences, 160, 109917.

Sidek Noah. (2008). Perkembangan Kerjaya Teori dan Praktis. Universiti Putra Malaysia, Serdang.

Soric, I., Penezic, Z. \& Buric, I. (2017). The Big Five personality trets, goal orientations, and academic achievement. Learning and Individual Differences, 54, 126-134.

Stajkovic, A. D., Bandura, A., Locke, E. A. Lee, D. \& Sergent, K. (2018). Test of three conceptual models of influence of the big five personality trets and self-efficacy on academic performance: A meta-analytic path-analysis. Personality and Individual Differences, 120, 238-245.

Steinmayr, R. \& Kessels, U. (2017). Good at school=successful on the job? Explaining gender differences in scholastic and vocational success. Personality and Individual Differences, 105, 107-115.

Wojciechowska, J. R., Wojcieiechowski J. \& Stolarski, M. (2021). Do time perspectives predict school performance beyond intelligence and personality? Personality and Individual Differences, 172, 110594.

Zhang, J., \& Ziegler, M. (2016). How do the big five influence scholastic performance? A big five-narrow trets model or a double mediation model. Learning and Individual Differences, 50, 93-102.

Zhang, J., \& Ziegler, M. (2018). Why do personality trets predict scholastic performance? A three-wave longitudinal study. Journal of Research in Personality, 74, 182-193. 